\title{
Labour exploitation as corporate crime and harm: outsourcing responsibility in food production and cleaning services supply chains
}

\begin{abstract}
The exploitation of workers can be understood on a spectrum of 'less severe' to 'severe' acts or omissions, where less severe exploitation can create conditions for severe exploitation to develop. Exploitation is not an isolated phenomenon perpetrated solely by 'criminals', but is closely related to developments in the economy, labour markets and society at large. Exploitation is enabled through otherwise legitimate business practices that disadvantageously affect vulnerable workers in product and labour supply chains. In this article, labour exploitation - and ultimately human trafficking - is framed as a form of corporate crime due to the significant role that businesses and supply chains have in facilitating exploitation. This corporate crime lens therefore argues that labour exploitation is driven by common market factors and business processes, which are closely associated with inadequate regulatory oversight of exploitation in local supply chains. The article draws on qualitative, semi-structured interviews conducted with workers and supply chain stakeholders in the UK agri-food industry, as well as the Finnish cleaning industry. Through thematic analysis, the dynamics of industry, labour subcontracting, and a lack of regulatory oversight are discussed, which are framed as key factors that enable exploitation to occur. Ultimately the corporate crime lens emphasises the economic, political and societal context in which exploitation takes place, and by doing so, uncovers the structural nature of such crimes.
\end{abstract}

Keywords: labour exploitation, human trafficking, corporate crime, supply chains

\section{Introduction}

The research agenda on labour exploitation has expanded significantly since the early 2000s, including academic, industry, and public perspectives (Crane et al. 2019; CIOB 2018; FRA 2015; GLA 2015). Part of this agenda has included efforts from the discipline of political economy to examine the causes of and solutions to labour exploitation as part of societal structures (states and corporations) - rather than being exclusively driven by individual criminals or organised crime groups (LeBaron et al. 2018). Running parallel to such arguments is the sphere of organisational or corporate crime, which emphasises the role of systemic business and market pressures in facilitating illegal or harmful actions, either by intent or negligence (Pearce and Tombs 1998). The primary purpose of this paper is to frame the discussion of labour exploitation through a corporate crime lens, thereby beginning to integrate the two perspectives. This framing is particularly useful from a criminological perspective, which tends to emphasise individual perpetrators and the most 
severe exploitation, which is an important, albeit limited part of the problem (Davies 2018; Scott 2017). Therefore, although a vast body of literature exists on the respective areas of labour exploitation and corporate crime, few researchers have developed an explicit connection between the two concepts (although see: Burnett and Whyte 2010; Ollus 2016a; de Vries 2018) The advantage of making such a connection is found at pivotal points of both research areas: how exploitation emerges from legitimate business actions (or omissions), supply chain and market activities, as well as limitations with the broader regulatory framework.

In this paper, the framing of labour exploitation as a form of corporate crime is complemented by data from two research projects previously conducted by the authors: one that focused on agrifood production in the UK (Davies 2018; Davies, forthcoming); and the other on cleaning services in Finland (Ollus 2016b; Ollus and Jokinen 2013). The two industries are examples of sectors that have undergone many changes in recent decades. Both the agri-food and cleaning industries are labour-intensive, and have undergone shifts towards flexible employment practices associated with temporary, part-time agency work, subcontractors, and self-employment (Lever and Milbourne 2017; Wilson and Ebert 2013; Kautonen et al. 2009). Both sectors have experienced an influx of migrant workers entering these labour-intensive and low-paid industries, coupled with larger structural economic and societal changes (Beck 2000; Gray 2004). At the same time, both countries have in principle emphasised the prevention of illegal activity associated with labour exploitation in policy and practice - perhaps more so than many other European countries. Although the UK and Finland are in many respects different when it comes to immigration and (migrant) labour policies (Koikkalainen et al 2011; Wilkinson and Craig 2011), the phenomenon of migrant worker exploitation shows many similarities. Given that many forms of exploitation are a universal phenomenon that emerge from structural changes within the economy and society, the discussion of the respective UK and Finnish sectors is a case in point. Since both studies were pursued as separate projects, the intention is not to generate a direct comparison, but to illustrate and suggest how exploitation is rooted in different sectors and and business practices across different countries.

As a definitional note, labour exploitation is defined here as a spectrum, ranging from 'severe exploitation, i.e. criminalised practices such as human trafficking and forced labour on one 
extreme, to 'routine' or 'less severe' exploitation on the other that typically breach labour law, for example underpayment and unfair dismissal. There are a number of grey areas associated with these terms, namely controversial practices that may be legal but which are seen as 'ethically' or 'morally' problematic, such as long working hours and flexible employment contracts that transfer economic risk to workers (Lambert 2008; Stone 2005). In this paper, the notion of corporate crime and its connection to labour exploitation is outlined, which is followed by an overview of industry and supply chain dynamics in UK agri-food production and the Finnish cleaning industry. Key findings from the two industries are then discussed, with a focus on examples of exploitation occurring in supply chains.

\section{Framing corporate crime and harm}

There is a significant literature on corporate crime that focuses on serious offences facilitated by companies and individuals working for them, including corruption (Standing 2015), toxic oil spills (Ruggiero and South 2010), health and safety hazards (Alvesalo and Whyte 2007), and food fraud (Lord et al. 2017). While it is a contested notion, corporate crime can be defined as 'any act committed by corporations that is punished by the state, regardless of whether it is punished under administrative, civil, or criminal law. This broadens the definition of crime beyond the criminal law, which is the only governmental action for ordinary offenders' (Clinard and Yeager 1980: 16). Because many forms of labour exploitation do not typically meet the thresholds needed for legal intervention, this article also uses the more inclusive term of 'corporate harm'. The definition adopted in this paper goes further than Clinard and Yeager's (1980) definition, since corporate harm that emerges from legal practices, such as zero-hours contracts and subcontracting is included; and as others point out (FLEX 2018), some forms of exploitation are legal, albeit 'ethically' controversial. It is recognised that such an approach moves closer towards the sphere of social harm, which is why the notion of a 'corporate crime continuum' is discussed below, which ranges from Clinard and Yeager's (1980) definition based on legal mechanisms, towards actions that may not breach criminal-legal frameworks. Notwithstanding the tensions between 'crime' and 'harm', harm can loosely be understood as breaches of stakeholders' legitimate interests, including physical, psychological, material, or privacy-related breaches (Greenfield and Paoli 2013). 
By association, the legal literature on corporate crime tends to critique notions of 'wilfulness' and decision-making associated with mens rea and actus reus, and instead argues for these decisions to be understood in the context of broader organisational processes (Lee and Gailey 2007). By extension, it discusses how far the actions of individuals can be attributed to corporations. As Gobert and Punch (2003: 26) assert, individuals should not be made scapegoats for corporate failures, but neither should corporations become scapegoats for an individual's derelictions - albeit this point of culpability is more complex when such individuals are decision-makers such as directors (Nietsch 2017).

Regarding individual and corporate liability, at least in UK law, statutes tend to impose criminal sanctions on companies on an irregular basis, largely due to the lack of a unified criminal code as seen in most continental European states (Gobert 2014: 315). Therefore, while specific criminal statutes such as the Bribery Act 2010 create liability for individuals and companies, if a statute does not contain a test for corporate liability, the courts would rely on the default common law 'identification' test of liability. This test would hold a company liable if an individual within it were identified as part of its 'directing mind and will' (Gobert 2014: 315-316). In Finland liability may ensure if someone commits a criminal offence on behalf of the corporation or in its operations (Alvesalo-Kuusi and Lähteenmäki 2016). Corporate criminal liability was first introduced in Finland 1995 but the scope of the law has later been extended to cover occupational safety and work-related crimes. Sanctions for such crimes are commonly directed at individuals at the supervisory or middle management levels, and overall, only a quarter of offences are prosecuted (Alvesalo-Kuusi et al. 2017). From a corporate crime perspective, these complexities are reflected in difficulties associated with holding companies responsible for labour exploitation.

In any event, corporate crime is generally understood as serious crimes facilitated by corporations and individuals within them. Based on Clinard and Yeager's (1980) definition, corporate crimes emerge in different ways: through intentional, systematic and well-planned deception, or as a result of carelessness and negligence (Tombs and Whyte 2015: 34). The state's willingness to tackle corporate crime depends on several factors: the strength of the forces promoting and opposing regulation, the type of corporate crime and its visibility, the perceived regulatory alternatives, the relation of the corporate crime to the needs of capital, its relation to dominant societal values, and 
the past and present relationship of the state to the major classes (Snider 1991: 218). Corporate conduct is often not subject to criminal law, and corporate action (and wrongdoings) are typically dealt with by regulatory agencies rather than criminal justice actors. States are reluctant to address and punish corporations, since they are dependent on companies for investment and economic growth (Tombs and Whyte 2015).

Corporate crime integrates closely with the notion of labour exploitation, due to the role of companies in enabling exploitation, as well as their potential to address it. In recent years there have been numerous arguments that show how exploitation is rooted in businesses, their supply chains, as well as markets and the broader political-economic context, rather than solely being driven by individual criminals, rogue employers and organised crime groups (Allain et al. 2013; FRA 2015). This body of literature seldom engages with the dynamics of corporate crime (although see Ollus 2016a; Tombs and Whyte 2015). However, the spheres of corporate crime and the political economy literature on labour exploitation have in common their explanations for crime and exploitation as rooted in systemic state-corporate practices. Framing labour exploitation through a corporate crime lens provides the basis for a stronger integration between the two areas, especially since some aspects of criminology tend to focus on severe and individualised practices rather than systemic explanations.

Related to this corporate crime framing, calling all exploitation 'crime' is problematic due to the under-reporting of many cases, as well as the reality that many forms of labour abuse are addressed by labour law and regulatory bodies, not the criminal justice system. This point is well grounded in existing literature as part of discussions on an exploitation spectrum or continuum, ranging from extreme, criminalised practices towards 'less severe' routine practices (Andrees 2008; Skrivankova 2010). Related to this exploitation spectrum, it is also fitting to recognise the more inclusive term of 'corporate harm' which includes actions or processes that may not be criminalised, reported, or criminally prosecuted, but which are still harmful to workers. Common examples of this may include zero hours contracts, which are legal but 'ethically' dubious, since they are synonymous with underpayment, demeaning work, a lack of job security, and longer term mental health problems. Therefore, parallel to the exploitation continuum is a continuum of corporate crime and harm. 
The idea of a corporate crime continuum principally includes the fact that there are more severe and criminalised practices on one extreme, and more ambiguous offences that would either be addressed by non-criminal means, or that occur beyond the scope of legal frameworks. Such a continuum can refer to incidents that occur in practice, not just by design, since in theory criminalised corporate practices may still be addressed by less coercive means than the criminal justice system. Just as there is ambiguity on the exploitation spectrum regarding at which precise point routine exploitation becomes severe exploitation (and vice versa), the same can be said for the corporate crime continuum. In other words, the lines between corporate crime and harm are also blurred due to legal and ethical complexities associated with business practices. Also, as Aubert (1952: 266) once argued when discussing white-collar crimes, these problems cannot be resolved by trying to categorise certain practices as 'crimes' or 'not crimes' - it is their contested nature that makes them sociologically relevant. In related spheres, Kauzlarich et al. (2003) refer to a 'complicity continuum of state crime' in order to demonstrate how states can actively conduct crime by commission on one extreme, or more 'passively' facilitate it through omission on the other. However, the corporate crime continuum referred to for the purposes of this paper integrates more closely with the labour exploitation continuum. Therefore, these contested notions of corporate crime and harm, when applied to the sphere of labour exploitation, are particularly relevant when considering routine exploitation. This is due to the fact that since routine exploitation is not typically grounded in criminal codes, it is not necessarily corporate crime in the traditional sense, but part of the same phenomenon associated with systemic problems in businesses, supply chains, markets, and the broader political-economic context.

\section{Exploitative dynamics of industry and supply chains}

Based on the work of critical scholars, there is literature that argues for political economy and structures (state and corporations) to be focal points when considering the causes of and solutions to labour exploitation (Crane et al. 2019; Scott 2017). This work posits that exploitation is systemic to structures, rather than solely driven by individual criminals. As part of this emphasis, the discourse around severe exploitation and individual perpetrators is partial, as well as politically charged. Business actors tend to emphasise that exploitation is exceptional and only committed by 
few "rogue" actors, such as those with connections to organised crime and other criminal groups. Many of the regulatory approaches indeed focus on tackling this type of exploitation. However, there are a number of exploitative practices that occur beyond the most severe and evident. In addition, governments' desires to tackle severe exploitation - such as human trafficking - may be tied to other priorities, such as border and immigration control (O'Connell Davidson 2010; Aradau 2004), while sidelining the more mundane forms of exploitation. These concerns have parallels with the areas of corporate crime and corporate harm, whereby particular sectors may be seen as 'high risk' or vulnerable to exploitation.

As discussed by Geddes and Scott (2010: 193), the UK agri-food industry has shifted significantly from 'primary' production on farms and fields to 'secondary' processing in factories, whereby casual labour has become a permanent feature of production. In addition, the dominance of supermarkets has reduced the number of smaller food outlets over time, which has underpinned a period of low-priced food that appeals to consumers (ibid.: 195). In Finland, and indeed elsewhere in Europe, much of the cleaning work that was previously done in-house is now outsourced. Although outsourcing is not a novelty in the cleaning business (Bernstein 1986), the increased competition in the field has led to competition through price-setting, poor quality cleaning services and also bad wages and working conditions for cleaners (Abbasian and Hellgren 2012; Koessl 2012; Refslund 2014).

Exploitation occurs when labour regulations are not enforced, and where production patterns put suppliers under pressure (Andrees 2008). The role of product and labour supply chains in facilitating exploitation is well established in existing research (Allain et al. 2013; Barrientos 2013). In broad terms, a supply chain can be understood as an interdependent relationship between producers, processors, buyers and consumers, where raw materials are transformed into final products, and information (demand, feedback, complaints) flows back down the supply chain (Stevens 1989). However, due to the vast number of buyers, who may purchase the same or different products from numerous suppliers depending on season or fluctuating prices, it may be more accurate to refer to the notion of 'supply networks' to reflect this complexity. These networks may cover national and global areas, yet in many cases have exploitative dynamics. Depending on the degree of supply chain complexity, such as subcontracting or use of casual labour, buyers may 
be unaware what impacts their decisions may have beyond companies that they interact with on a regular basis.

In the corporate crime literature, the supply chain is described as a technique for "contracting out crime" (Tombs and Whyte 2015:31). When the margins become tighter, at some point in the chain, the only way of meeting contractual obligations while still making a profit is to break the law (ibid.). This seems to apply to the use of supply chains and outsourcing in the UK agri-food industry and the Finnish cleaning sector (among others). Outsourcing may refer to businesses devolving some of their business activities to other companies, who may have the capacity, expertise and resources that the other businesses lack. Subcontracting tends to be more specific, and in the UK primarily involves businesses using labour intermediaries to recruit workers and manage employment relationships, including contracts and salary payments. In the Finnish cleaning sector, cleaners are usually employed by the cleaning company they work for. However, there is now an increasing use of franchising, i.e. self-employment where companies subcontract the cleaning to self-employed workers, who pay a franchising fee to the company that provides them with contracts.

Labour subcontracting in particular is highlighted as a challenge. In the UK, the role of 'gangmasters' or labour intermediaries in the agri-food industries revolves around providing casual, short-term, flexible labour to supply chain businesses, frequently at short notice. In the Finnish cleaning sector, the vast majority of companies are micro-businesses with less than five employees (Lith 2012). Despite the large number of small companies, the sector is strongly concentrated in the hands of a few large corporations (ibid.). Many of the large companies also outsource some of their work to smaller companies. While the large companies theoretically abide by all rules and regulations, problems of unclear employment and exploitation exist particularly in the smaller companies down the supply chain. Subcontracting in broader terms can be a helpful and essential aspect of business activity, allowing smaller businesses to draw on external expertise that is otherwise not available. While the role of such casual labour is arguably essential for fastpaced industries such as agri-food production, there are significant concerns around the informality and poor oversight of such labour intermediaries. As Allain et al. (2013:39) argue, this informality surrounding labour supply chains can be the 'gateway to forced labour'. 
The structure of supply chains in the UK food production industry and the link to exploitative labour practices is well illustrated by Crane et al $(2019,94)$. Figure 1 outlines the relationship between product and labour supply, and identifies where exploitation occurs (adapted from Crane et al 2019; the layout of the original figure amended by the authors). The structure of subcontracting in the Finnish cleaning industry is illustrated in figure 2. The figure illustrates how exploitation may be present towards the lower end of the subcontracting chain.

FIG 1. Product and labour supply chains giving rise to forced labor in the food industry, adapted from Crane et al $(2019,94)$.

FIG 2. Subcontracting chains and sites of possible exploitation in the Finnish cleaning industry.

The perspectives of corporate crime and harm relate closely to these supply chain processes, since in a business or supply chain context, there are unlikely to be high levels of intentional and interpersonal 'criminality'. Many people within businesses simply want their organisation to make profits, or at least avoid losses, and seem to be increasingly recognising the importance of supply chain transparency and responsible business conduct in relation to 'modern slavery' and labour exploitation. Yet an emphasis on corporate crime and harm provides a strong basis on which to move beyond the narrower ideas of criminal intent or interpersonal violence (the former of which may be highly problematic to establish in a business context), and instead focus on processes as well as consequences.

\section{Regulatory oversight in the UK and Finland}

Terms such as regulation, governance, and in this context, supply chain oversight, have all gained attention along with the increasing prominence of forced labour, human trafficking and labour exploitation. While there is insufficient space here to examine all regulatory developments with the rigour they deserve, different forms of oversight arguably have a role in the context of exploitation. For the purposes of this discussion, 'top down' oversight is referred to, such as: state regulation, consisting of criminal law, civil law, as well as the police and specialist regulatory bodies; 'corporate social responsibility' (CSR), here including supply chain transparency provisions imposed by states onto some businesses; as well as 'bottom up' oversight referring to 
the role of labour movements and trade unions. The strengths and limitations of these interventions have been examined in detail elsewhere (Drahos and Krygier 2017); however, the lack of a unified 'labour inspectorate' (in the UK context at least) means that responsibility for exploitation occurring in businesses and supply chains is fragmented across numerous organisations as well as government departments.

In the UK, responsibility for tackling labour market exploitation is perhaps most prominently associated with the Gangmasters and Labour Abuse Authority (GLAA), which regulates labour providers in the agri-food sectors. The recently appointed Director of Labour Market Enforcement (DLME) begins to consolidate resources across some agencies that tackle exploitation, but this is far from comprehensive and there have been concerns that this may lead to competition between agencies for resources, rather than the intended co-operation. In Finland the Occupational Safety and Health Administration (OSHA) is the main authority responsible for monitoring safety, health and working conditions. Specialised labour inspectors monitor employers who employ migrant workers. The labour inspectors have a limited mandate: they check whether workers have a valid work permit, and check the overall working and employment conditions, and give recommendations to the employer in cases of misconduct. The inspectors are also obliged to report to the police if they suspect any number of labour crimes; albeit trafficking in human beings is not included. In practical terms, however, it is often the labour inspectors who are in a position to identify instances of exploitation. The use of subcontractors is regulated through the Act on the Contractor's Obligations and Liability when Work is Contracted Out, which stipulates that subcontractors are obliged to observe the relevant terms of employment and wages. Specialised OSHA inspectors are responsible for monitoring adherence with this act. Despite the existence of laws and regulations that govern the work against labour exploitation in Finland, there is no systematic or structured approach to countering exploitation. There is for instance no specialised police unit focusing on labour exploitation or even human trafficking. This has implications on how cases of labour exploitation are investigated, perceived, and treated (Alvesalo-Kuusi, Jokinen and Ollus 2014). Occupational safety and health crimes have traditionally not been prioritised among the police, which has implications also on the treatment of labour exploitation and the collaboration with labour inspectors. 
Part of the reason for the focus in this paper on the UK and Finnish contexts stems from regulatory differences between the two countries, which ultimately form a critical part of supply chain dynamics. As noted above, the UK has no national 'labour inspectorate' that has complete oversight of the regulatory context in relation to labour exploitation. In Finland, however, the OSHA has a mandate to monitor forms of labour exploitation, and to a certain extent also human trafficking. There are, of course, differences in the way employment is structured in the UK and Finland. While Finland does not have a minimum wage, almost all sectors and employees are covered by collective agreements, and the level of unionization is high with the exception of migrant workers. In contrast, the UK has a national minimum wage but low levels of unionisation, especially among migrant workers. These differences, while interesting in their own right, suggest that 'strong regulatory contexts' alone do not deter labour exploitation and trafficking from occurring, which reinforces the complexity of supply chain practices as prominent issues when conducting research in this area. In the analysis section, the current regulatory approach and its shortcomings in addressing labour exploitation will be further examined.

\section{Methods}

The empirical work that informs this paper is two-fold, and stems from separate research projects conducted in the UK and Finland. In the UK study, qualitative, semi-structured interviews were conducted with migrant labourers and supply chain stakeholders from the agri-food industries, including those working on farm production and in food processing factories $(\mathrm{N}=27)$. In total, 14 migrant workers were interviewed, as well as 13 stakeholders (including buyers $(\mathrm{N}=4)$, workers' rights advocates $(\mathrm{N}=3)$, gangmasters/intermediaries $(\mathrm{N}=2)$, regulators $(\mathrm{N}=1)$, trade union $(\mathrm{N}=1)$ and legal $(\mathrm{N}=1)$ representatives). A more detailed discussion on the original study can be found in the author's previous work (Davies 2018; Davies, forthcoming). As noted in this previous work, although the sample is small, it is intended to illustrate recurring practices in an industry that is vulnerable to labour exploitation. The data was used to develop a broader argument that 'routine exploitation' risks being neglected when contrasted with severe labour exploitation. Using a relatively small sample to develop a broader point that can subsequently be 'tested' by further empirical work is regarded as a 'grounded' approach to research (ANON). A similar approach was used in an earlier study conducted in Finland. In Finland, the data consisted of semi-structured qualitative interviews with stakeholders and migrant workers $(\mathrm{N}=38)$. The interviews were carried 
out in 2013 as part of a research project on labour exploitation in the restaurant and cleaning industries. The original study can be found in the author's previous work (Ollus and Jokinen 2013) $)^{1}$. For the purposes of this article, data focusing on the cleaning industry was selected. Participants of the semi-structured qualitative interviews included both experts $(\mathrm{N}=28)$ and migrant workers $(\mathrm{N}=10)$. The interviewees include representatives of employers and recruitment agencies $(\mathrm{N}=6)$, representatives of trade unions $(\mathrm{N}=8)$, representatives of organisations providing support to migrants $(\mathrm{N}=5)$, representatives of law enforcement, tax authorities and labour inspectors $(\mathrm{N}=6)$, and others $(\mathrm{N}=3)$.

For the purposes of this article, the focus is on the consequences of subcontracting, examples of exploitation, as well as regulatory oversight. A thematic analysis was conducted of both datasets for each of the authors' respective projects (Davies 2018; Ollus and Jokinen 2013). Attride-Stirling (2001) asserts that thematic analysis provides a non-prescriptive yet rigorous basis to analyse qualitative data through identifying initial codes that are later organised into key themes. Given the similar sample sizes and subject areas that each project examined, such as supply chain dynamics, this provided a basis on which to discuss similarities and differences between the respective UK and Finnish industries. In this case, the authors identified common discussion points that each of the projects had addressed, including labour subcontracting, and weaknesses of the regulatory context.

Limitations of the data include the fact that the samples are convenience samples, combined with snowballing for additional respondents, and are not representative of all conduct or practices in the two sectors or countries. Because both samples focused on understanding the forms of exploitative conduct experienced by migrant workers, it is possible that the data overemphasise certain types of conduct and rationalisations at the expense of others. Despite the effort here at some crosscountry comparison, the data came from two different projects, countries and sectors; hence, there are notable differences between the two sectors. Directly comparing both countries' regulatory systems, as well as oversight of the specific sectors, is not easily achievable due to differing

\footnotetext{
${ }^{1}$ Despite the empirical data being some years old, the experiences accounted for by the interviewed workers remains relevant. This is evidenced by information from the main trade union for the service sector, the main organisation assisting victims of labour exploitation as well as the labour inspectorate in Finland, which have all recently encountered migrant workers facing similar experiences as those recorded in 2013.
} 
histories and political-legal systems. In addition, the respective sample sizes from each project are small and were based on case studies - expanding both the number of participants and sectors under consideration would be a helpful exercise for future research in order to add further credibility to the arguments. These limitations are recognised, and as stated, the intention here is to be illustrative and provide an explorative discussion, rather than a statistically representative and explanatory one. However, since the argument centres on supply chains and networks as a key facilitator of labour exploitation, it is helpful to examine the organisational processes that shape these conditions, some of which apply to sectors regardless of location, context, and type of business. Therefore, common themes and distinctions between the two countries will be discussed where appropriate.

\section{Moving from individual to structural explanations for labour exploitation}

The analysis discusses the argument that labour exploitation and ultimately, trafficking, is driven by market, business and supply chain processes, rather than being an exclusive problem of criminal organisations and individual 'rogues' across industries. In order to unpack this argument, the two industries are considered in order to suggest how issues and challenges inherent to them can serve as catalysts for exploitation. Specific business activities associated with labour subcontracting are then discussed, as well as the regulatory context. These factors interlink with existing discussions on corporate crime, whereby legitimate actors, businesses, and markets are central to explaining how and why criminal and harmful practices occur.

\section{Industry dynamics}

In both the UK and Finnish datasets there were examples of exploitation: migrant workers who worked long hours for little pay, who were afraid of their employers, who were threatened with a termination of their contract if they refuse work, and who were unable to change employment due to a lack of alternatives. It is crucial to note that the interviewed workers themselves considered their experiences as exploitative. While the actions of individual perpetrators and even organised criminal activity are important in explaining exploitation at the general level, the data from both countries suggests that exploitation is not necessary directly linked to criminal conduct, but rather to inherent features and operating procedures of industries. These dynamics of industries become potentially significant factors that enable exploitation: 
... sometimes, if it's summer, because it's a food factory, then we have a peak season, or peak times in the week. Or maybe when it's the Christmas period. Because of that, we are trying to sell as many goods as possible. So the pressure is on, and you have to go very fast and everything. (Migrant worker of African origin, UK)

Clients don't want to pay for cleaning. Previously cleaning was done in the evening, but now the most hectic time is from 6-8am. That's when you need a lot of people. [...] The cheapest bid is always the one where they have reduced the extent of the cleaning. (Shop steward in a major cleaning company, Finland)

From these extracts, there are a number of important issues that signpost possible vulnerabilities within the respective UK and Finnish industries. Due to the largely seasonal nature of food production, combined with unexpected fluctuations in demand, these represent tensions that affect food businesses. Similarly, in cleaning, there are peak times where demand for services is highest, which means that more workers are required at certain times of the day. Such fast-paced, intense work has the potential to result in exploitative conditions and longer-term health problems. However, this type of flexibility remains a critical function of both industries at least in the current economic era, which suggests that there is a limit to how far individual employers can influence such conditions.

Since suppliers/providers have contractual obligations, there is usually a limited time available to process food or complete the cleaning tasks, while meeting their orders in a timely manner. Failing to do so risks repercussions in the form of reduced payments or future business orders. These contractual obligations need to be finely balanced with employment practices, where the amount of labour needed can change on a regular basis. Due to price pressures, narrow profit margins, the need for timely orders/service, and fluctuating demand, this can result in work becoming informalised and intensified in order to meet contractual obligations. This informalisation can come in numerous forms, including flexible employment contracts and the use of labour market intermediaries to supply cheaper labour than the costs of full employment. In other words, many employers do not necessarily act with malice or intent to cause harm to their workforce but are trying to do the best for their business by meeting orders and maximizing profits, or at least minimizing losses. 
On the other hand, interviewed workers as well as practitioners spoke about small cleaning companies that abuse the vulnerabilities of migrant workers, i.e. their lack of alternatives, their lack of knowledge of their rights, and their lack of other resources. While such companies can be deemed as abusive and 'bad' employers, such companies exist within the structures of the industry. The industry dynamics imply that features and processes inherent to legitimate businesses and economic sectors play an important part in shaping the conditions necessary to facilitate exploitation. Such factors strongly relate back to the notion of corporate crime, which places a strong emphasis on vulnerabilities to unethical and illegal practices within otherwise legitimate industries (Tombs and Whyte 2015). Among these dynamics is the issue of outsourcing and subcontracting. The associated informality with these practices has been described as the 'gateway' to more serious forms of exploitation, such as forced labour, and is an area which we now examine in greater detail.

\section{Outsourcing and subcontracting}

Lengthy, complex supply chains and the subcontracting of workers from mainstream businesses to labour providers, has become an increasingly important dynamic in local and global supply networks in recent years (e.g. Barrientos 2013; LeBaron et al. 2018). Participants highlighted these issues as significant areas of concern:

The problem is also the length of the supply chain, the shorter you can make it, the more responsibility companies can take. There's also the classic, a lot of campaigners over the years have used the, all you need to do to pay someone a decent wage is pay $2 p$ more for a box of fruit or whatever. But the longer the supply chain, the harder it is for that $2 p$ to be enough, because all the people in between you and them want a piece of the increase in price as well. So suddenly it starts to become a price that retailers don't want to stick on their fruit products, because it does actually make them noticeably more expensive than their competitors, whereas $2 p$ obviously wouldn't. (Trade Union Representative, UK)

When there is a big cleaning company and they subcontract the jobs to immigrant-owned cleaning companies where there is often only one person, the owner of the company is the cleaner. He is getting a sub-contract and so they are reducing the prices in this way and the big company gets a certain margin and then the one person who has his own company gets a smaller amount and then maybe again saying that OK I get as much and as many 
contracts as I can. Suddenly he is having too many and then again subcontracts to someone else, you can do this and I can give you this. Again, the price goes lower and lower. (Service provider for immigrants, Finland)

It is with these legal processes that the structural and endemic factors associated with labour exploitation become clear, as opposed to the actions of a distinct 'criminal sector' or individual criminals. In both the UK food production and the Finnish cleaning industry subcontracting is frequently associated with flexible employment contracts, including 'zero hours contracts' that do not guarantee a set number of weekly hours. With these processes, there is evidence to suggest that longer and more complex supply networks, which may prove to be profitable to more powerful supply chain actors, generate more pressure on less powerful actors, which in turn ensures that these costs and risks generate vulnerabilities to exploitation.

The UK trade union representative highlights complex supply networks as a significant issue in relation to associated employment practices and conditions. There is recognition that shorter supply networks, both in terms of geographical distance and number of actors involved, reduces the risks and vulnerabilities that can result in exploitative practices, regardless of how well intentioned individual supply chain actors might be. Related to this complex supply network issue, the union representative provides an example that even though marginal price increases for products may in principle seem to deliver benefits to workers through improved wages, more complex networks make this less likely due to a larger number of actors wanting a share in this price increase. The Finnish service provider emphasises that the longer the subcontracting chain, the less there is money at the end of the chain, again affecting the salary of the cleaner performing the work.

While there are distinctions between subcontracting and casual employment practices such as 'zero-hours contracts', the two are frequently found in conjunction with each other. This is especially the case in industries where demand for products and services fluctuates on a regular basis, which makes providing direct, permanent employment to workers more expensive to maintain - an issue that the following gangmaster highlights. 
... seasonal contracts, zero-hours contracts, we cannot really ... I mean, they're not very useful if you want to stay in the UK, let's put it like that. So we cannot really guarantee any work as such, it all depends on the demand, and our crop. So if we haven't got orders or our crop gets destroyed by the weather, there is no job basically for the people. (Gangmaster-1, UK)

Cleaning work is labour intensive, but the demand for workers is unevenly distributed. This means that many cleaning workers in Finland are working on part-time, temporary and zero-hours contracts. A worker on a full-time contract has to be offered work even when the demand fluctuates (and paid when he or she is off work due to illness). From the perspective of the cleaning companies, it is easier to manage the workload when workers are employed on a part-time, and on-demand basis. Several of the interviewed migrant cleaning workers testified that they were unable to secure a sufficient number of working hours for a decent wage. The workers would have wanted to work more, but were afraid of demanding more work at the risk of losing the job altogether. Some workers said they were afraid of complaining about the conditions of work, as this would also have influenced their number of working hours.

If you opened your mouth and said that something is not to your liking, then you were immediately influenced through work. You were not given any work until you said to everybody that yes, yes, this is how it should be. Then you got lots of work. But when you said that you are tired and want to leave earlier on that day, then for five weeks several jobs were taken away. (Migrant worker of European origin, Finland)

From a business angle, it arguably makes little sense to retain permanent employees if there is a lack of work to justify such costs, which is why subcontracting is seen as helpful from this angle. Indeed, subcontracting may assist businesses to remain competitive. However, the informality associated with subcontracting and casual employment 'mystifies' supply networks, by outsourcing responsibility for labour conditions from central, rule-abiding businesses to intermediaries or small and micro businesses, who may be difficult to monitor from a supply chain management perspective, as exemplified by the practices of outsourcing in the Finnish cleaning industry. 
Therefore, supply chain actors may not necessarily intend any harm to occur to workers further down the process, but this may nevertheless result from other businesses trying to maximise profits, minimise their losses, and keep their business competitive. In turn, this raises the issue of whether it is reasonable to expect companies such as buyers and retailers to know of every business transaction in their supply networks, since multiple suppliers and subcontractors may be used for the same product. Arguably such monitoring would divert significant resources away from primary business activities and only encourage businesses to cut further corners in order to save time and resources. ${ }^{2}$ Hence, businesses arguably cannot and should not be responsible for regulating themselves, which begins to question whether other forms of regulatory oversight to monitor business activity and ethical practices are robust enough to prevent exploitation.

\section{Supply chain oversight and regulation}

As noted above, there are numerous regulatory interventions that relate to the spectrum of labour exploitation. Focusing on the 'top down' forms of state oversight, participants noted concerns related to one of the UK's key pieces of legislation, the Modern Slavery Act 2015:

The criminal justice system, that's absolutely the ideal way, because ultimately where exploitation leads to the denial of fundamental human rights, and also risking health and life, then that is a criminal act. The Modern Slavery Act up to a point reflects that in terms of exploitation here domestically. The transparency in supply chains stuff, although toothless, in conjunction with some of the financial laws which give extra territorial jurisdiction, is beginning to break down the barrier of, well it happened over there, it's nothing to do with us. So we hope that eventually these things will evolve, so that the teeth of the financial regulations and the principles of the Modern Slavery Act on labour exploitation come together to give something with teeth on labour exploitation. (Trade Union Representative, UK)

The extract reflects concern that the Act is limited in scope, and even 'toothless' as the union representative suggests. This may be because the Act's provisions relate only to the more severe, criminalised forms of exploitation, and only to larger companies. While it is not clear which financial laws are referred to in this extract as being able to give the Act more 'teeth', it is possible

\footnotetext{
${ }^{2}$ On the other hand, already in 1982, the Netherlands adopted chain liability legislation that applies to subcontracting processes (Houwerzijl and Peters 2008).
} 
that he refers to the Bribery Act 2010, which contains extraterritorial provisions for some offences committed outside the UK (Lord 2014: 71). In terms of establishing responsibility for exploitation, there are well trodden discussions within corporate crime over identifying the 'controlling mind' of organisations and the difficulties of proving criminal intent (Gobert and Punch 2003). This holds particular relevance when addressing supply chain practices, many of which span over more than one country. Due to these difficulties, specialist regulatory bodies and inspectors tend to emerge as an alternative option in the area of labour exploitation, since they do not necessarily adopt the same evidence thresholds needed for criminal prosecutions:

We carry out inspections together with the inspectors responsible for contractors' liability. They check the contracts. If it is severely underpriced, a negligence fee is imposed on the buyer.[...] They only check the contracts. The law stipulates that they need to ask what collective agreement the subcontractor uses. It is sufficient that the subcontractor announces which one they follow. Does the subcontractor understands what they tell us? The law needs to include a paragraph that the subcontractor must understand the contents of the collective agreement and how much workers should be paid. Now they just say that they follow this or that collective agreement. (Labour inspector, Finland)

Labour inspectors have the ability to issue notifications, penalty payments and prohibitions of operation on businesses without the time and costs associated with criminal trials. Of course, there are broader concerns regarding the status of fines as appropriate punishments for companies that commit illegal acts, since this risks giving the impression that these breaches are not 'real' crimes. However, the powers of Finnish labour inspectors is currently rather limited, and the notifications do not bring with them any repercussions unless the misconduct is significant. Interviewed stakeholders and workers alike called for increased powers to labour inspectors. Another solution would be to include trafficking in inspectors' mandate, and to enhance the investigative cooperation between the police and labour inspectors.

I think the [labour inspectorate] needs more powers. It's not just about giving your opinion on something, they should be able to do more than just give opinions on issues. I am saying so because there are some workers who do not know much of unions. Those people should be able to have protection from somewhere. [...] The companies know that the labour inspectorate cannot do anything. The company knows which of their workers are in the union and which are not. They know which workers they can rough handle and who they cannot. (Migrant worker of African origin, Finland) 
... unfortunately, the GLA [GLAA] ... hasn't got a lot of strength, hasn't got a lot of people working there, they can't cover the country. That's one of the problems with the GLA.I mean, of course we work with them and they examine us, make sure we're doing all the right things ... but the GLA haven't got any teeth, you know, they can do the odd person but they need far more strength. (Gangmaster-2, UK)

Providing further powers to regulatory bodies may seem like an appealing option to some stakeholders such as those advocating better working conditions, and regulatory bodies themselves. However, national governments have been reluctant to appear anti-business, and so limit the amount of state regulation, fearing that this will be branded as 'red tape' or as stifling economic growth (Snider 2009). Despite recent developments in the area of labour inspections and state regulatory bodies, such as the increasing remit and resources of the UK's GLAA ${ }^{3}$, this is a relatively new and ongoing development, despite there having been calls for a wider GLAA remit over several years. While the UK and Finland, as most other European countries, have some form of state regulatory agency (or agencies) that oversee labour conditions, recruiters and businesses in order to prevent labour exploitation, there are clearly inconsistencies and limitations with how they operate. In spite of individual differences between countries, an overall picture of a somewhat 'light touch' regulatory approach emerges, which researchers in the corporate crime literature signpost as a key vulnerability to unethical and illegal practices occurring within organisations and across their means of production.

\section{Discussion and conclusion}

From the data discussed above, there is a case for arguing that there are systemic problems with corporations overseeing a range of exploitative practices across numerous countries. The examples of the UK and Finland are examples that demonstrate this point. Volatile industry dynamics, routine subcontracting, and limited regulatory oversight all contribute to a 'race to the bottom' which erodes labour protections and exposes workers to routinised and normalised forms of exploitation. These points relate to assertions in existing work that corporate harm is synonymous with the capitalist model that is dominant in many developed and developing countries (Lloyd

\footnotetext{
${ }^{3}$ As of May, 2017 the GLA became the GLAA, and received increased powers to investigate labour abuse across the UK labour market.
} 
2018; Pemberton 2015; Scott 2017). Nevertheless, there are interesting nuances between the UK and Finnish contexts. For instance, UK labour market enforcement is more fragmented than Finland, not least due to the number of enforcement bodies that regulate against exploitative practices (CIOB 2018). In Finland, labour inspectors as well as criminal justice actors have addressed severe forms of exploitation, in particular. However, while there is a structural readiness to tackle exploitation in terms of legislation, the conceptual readiness to recognise and address exploitation is still limited (Ollus and Alvesalo-Kuusi 2012). In terms of the broader political economy, Finland adopts more of a social democratic model in line with neighbouring Scandinavian countries when compared to neoliberal models, of which the UK tends to be characterised (Pemberton 2015: 88). In other words, the social democratic model emphasises limited privatisation of key industries, stronger trade unionisation, and more generous welfare systems. This has to some extent hindered the more negative impacts of capitalist production on workers in comparison to countries such as the UK. The shift towards more flexible patterns of production and employment are affecting workers also in Finland, as suggested in this article. There are key nuances between countries, sectors and industries, and thus it is not feasible to develop a 'catch-all' response to corporate harm. However, it is crucial to note that corporate harm - in this case labour exploitation - contains universal features across countries and industries.

Viewing labour exploitation through a corporate crime lens has the advantage of encouraging criminology to examine exploitative practices beyond the most severe, and where there are not easily identifiable perpetrators and victims. In other words, a corporate crime framing places a stronger emphasis on systemic pressures within society, including states, business supply chains, and labour market regulation - all of which provide a richer understanding of labour exploitation when compared to individual criminality. By implication, the framing of a corporate crime continuum, which incorporates the notion of corporate harm, also has value by moving beyond the confines of criminal-legal definitions, and considering the legal mechanisms by which exploitation can and does occur across a range of countries and industries. The emphasis on the respective UK and Finnish industries in this paper is a case in point, rather than a generalisable explanation, yet demonstrates how 'lower-end' practices on the corporate crime continuum also occur due to embedded business and supply chain activities, and that severe exploitation is not the only outcome. 
In this paper it is argued that labour exploitation and ultimately human trafficking can be understood as a form of corporate crime, by situating business activities, supply chain practices, and the regulatory context at the centre of the explanation for harmful practices against workers. By examining the risks of labour exploitation within industries rather than just among individual actors, it is possible to develop more nuanced discussions of so-called 'grey areas' between legitimate and illegitimate (business) practices, legal and illegal markets, as well as the wider societal context within which these function. In particular, corporate crime provides a useful lens through which to frame these discussions on exploitation, by moving attention from intentional, interpersonal, and direct forms of harm towards unintentional, structural, and indirect harm. From a corporate crime perspective, many of these harmful practices may be neither criminalised nor criminally prosecuted, whereby the more inclusive notion of corporate harm emerges - especially if viewed on a corporate crime 'continuum' that begins to integrate with the exploitation continuum.

Both the UK food production industry and the Finnish cleaning sector are characterised by tight profit margins and fluctuations in demand, which translate into a need for labour flexibility. Both sectors are characterised by an increased use of subcontracting and outsourcing. The use of suppliers and subcontractors may result in an outsourcing of responsibility, in particular when there is limited oversight and liability further down the supply chain. Subcontracting and outsourcing therefore contribute to the risk of labour exploitation in the supply chain. In this article, the role of regulation and oversight has been discussed, with the assertion that existing frameworks are insufficient to deal with exploitation, in particular when it takes place within legitimate supply chains. While the UK Modern Slavery Act is an important step in addressing severe exploitation, it is less effective in tackling 'less severe' embedded forms of exploitation. Similarly in Finland, the oversight of transgressions of labour conditions remains insufficient. By framing exploitation as a form of corporate crime, it is possible to highlight that certain business practices, such as outsourcing and subcontracting, while being "legal", create situations of harm for workers in these sectors - hence the emphasis on corporate harm being part of the 'corporate crime' continuum. 
Some of the recurring processes in the discussion above are significant - for example, the need for companies to maximise profits, limited regulatory oversight, poor unionisation rates, and the availability of vulnerable workers. These factors interlink with poor work conditions that can deteriorate and so underpin exploitation ranging from relatively 'minor' breaches of employment law to more severe cases of 'modern slavery' that typically fall under the remit of criminal law

(France 2016). Ultimately a focus on labour exploitation and trafficking, framed through a corporate crime perspective, contributes to existing discussions by providing a rigorous analysis of legitimate market actors, businesses and supply chains. Such an approach, if expanded, has the potential to play a significant role in not only covering a wider range of economic sectors, but in considering to what extent these market processes are criminogenic.

\section{References}

Abbasian, S. \& Hellgren, C. (2012). Working Conditions for Female and Immigrant Cleaners in Stockholm County. An Intersectional Approach. Nordic Journal of Working Life Studies, 2(3), 161-181.

Allain J., Crane A., LeBaron G., \& Behbahani L. (2013). Forced Labour's Business Models and Supply Chains. York: Joseph Rowntree Foundation.

Alvesalo, A. and Whyte, D. (2007). Eyes Wide Shut: The Police Investigation of Safety Crimes. Crime, Law and Social Change, 48(1-2), 57-72.

Alvesalo-Kuusi, A., Jokinen, A. and Ollus, N (2014). The exploitation of migrant labour and the problems of control in Finland. In van Aerschot, P. (Ed.), The Integration and Protection of Immigrants. Canadian and Scandinavian Critiques (pp. 121-138). Ashgate: Hampshire.

Alvesalo-Kuusi, A. \& Lähteenmäki, L. (2016). Legislating for corporate criminal liability in Finland: 22-year long debate revisited. Journal of Scandinavian Studies in Criminology and Crime Prevention, 17(1), 53-69

Alvesalo-Kuusi, A., Lähteenmäki, L., Janhonen, M., Tapani, J. \& Räsänen, T. (2017). Yhteisövastuu, turvallisuus ja työturvallisuusrikos muuttuvan työelämän ja lainsäädännön käytännöissä (translation: Corporate responsibility, safety and occupational safety and health crimes in the changing practices of working life and legislation). Helsinki: Työterveyslaitos. 
Andrees, B. (2008). Forced Labour and Trafficking in Europe: How People Are Trapped In, Live Through and Come Out. Working Paper, Special Action Programme to Combat Forced Labour. Geneva: ILO.

Aradau, C. (2004). The Perverse Politics of Four-Letter Words: Risk and Pity in the Securitisation of Human Trafficking. Millennium: Journal of International Studies, 33(2), 251-77.

Attride-Stirling, J. (2001). Thematic Networks: An Analytic Tool for Qualitative Research. Qualitative Research, 1(3), 385-405.

Barrientos, S. (2013). "Labour Chains": Analysing the Role of Labour Contractors in Global Production Networks. The Journal of Development Studies, 49(8), 1058-1071.

Beck, U. (2000) The Brave New World of Work. Polity.

Bernstein, D. (1986). The subcontracting of cleaning work: a case in the casualization of labor. Sociological Review, 34(2), 396-422.

Burnett, J. \& Whyte, D. (2010). The wages of fear: Risk, safety and undocumented work. Leeds: PAFRAS and the University of Liverpool.

CIOB (2018) Construction and the Modern Slavery Act. Bracknell: CIOB.

Clinard, M., and Yeager, P. (1980) Corporate Crime. London: Transaction Publishers.

Crane A., LeBaron G., Allain J., and Behbahani L. (2019) 'Governance gaps in eradicating forced labour: from global to domestic supply chains'. Regulation \& Governance, 13(1), 86-106.

Davies, J. (forthcoming) 'Corporate harm and embedded labour exploitation in food supply networks'. European Journal of Criminology.

Davies, J. (2018) 'From severe to routine labour exploitation: the case of migrant workers in the UK food industry'. Criminology \& Criminal Justice. Epub ahead of print, 10 March 2018. DOI: $10.1177 / 1748895818762264$.

de Vries, I. (2018). Connected to crime: an exploration of the nesting of labour trafficking and exploitation in legitimate markets. British Journal of Criminology. Advance article published online, 21 June 2018. 
Drahos, P., \& Krygier, M. (2017). Regulation, Institutions and Networks. In Drahos, P. (Ed.), Regulatory Theory: Foundations and Applications (pp. 1-22). Acton: ANU Press.

FLEX (2018). Shaky Foundations: Labour Exploitation in London's Construction Sector. Focus On Labour Exploitation.

FRA (2015). Severe labor exploitation: workers moving within or into the European Union. States' obligations and victims' rights. European Union Agency for Fundamental Rights.

France, B. (2016). Labour Compliance to Exploitation and the Abuses In-Between. London: Labour Exploitation Advisory Group

Geddes A., \& Scott S. (2010). UK Food Businesses' Reliance on Low-Wage Migrant Labour: A Case of Choice or Constraint?. In Ruhs M., and Anderson B. (Eds.), Who Needs Migrant Workers? Labour Shortages, Immigration, and Public Policy (pp. 193-218). Oxford: Oxford University Press.

GLA (2015) Labour Exploitation: Spotting the Signs. Nottingham: Gangmasters Licensing Authority.

Gobert, J. (2014) Country Report: Finland. In Gobert,J., and Pascal, A. (Eds.), European Developments in Corporate Criminal Liability (pp. 234-239). Abingdon: Routledge.

Gobert J., \& Punch M. (2003). Rethinking Corporate Crime. Cambridge: Cambridge University Press.

Gray, A. (2004) Unsocial Europe: Social Protection or Flexploitation? London: Pluto Press.

Greenfield V.A., and Paoli, L. (2013) A framework to assess the harms of crimes. British Journal of Criminology, 53(5), 864-885.

Houwerzijl, M. \& Peters, S. (2008). Liability in subcontracting processes in the European construction sector: Netherlands. Dublin: European Foundation for the Improvement of Living and Working Conditions.

Kautonen, T., Palmroos, J. \& Vain, P. (2009). Involuntary self-employment in Finland: A bleak future? International Journal of Public Policy, 4, 533-548.

Kauzlarich, D., Mullins, C., and Matthews, R. (2003) 'A complicity continuum of state crime'. Contemporary Justice Review 6(3), 241-254. 
Koessl, G. (2012) Precariousness and futurity: the example of subcontracted cleaning workers in the banking and finance industry in London. Graduate Journal of Social Science, 9(2), 86108.

Koikkalainen, S., Tammilehto, T., Kangas, O., Katisko, M., Koskinen, S., \& Suikkanen, A. (2011). Welfare or work: migrants' selective integration in Finland. In Carmel, E., Cerami, A. \& Papadopoulos, T. (Eds.), Migration and Welfare in the 'New' Europe. Social Protection and the Challenges of Integration (pp. 143-158). Bristol: Policy Press.

Lambert, S. J. (2008). Passing the buck: Labor flexibility practices that transfer risk onto hourly workers, Human Relations, 61(9),1203-1227.

LeBaron, G., Howard, N., Thibos, C. \& Kyritsis, P. (2018). Confronting root causes: forced labour in global supply chains. Sheffield: Sheffield Political Economy Research Institute.

Lee M.T., Gailey J.A. (2007). Attributing Responsibility for Organizational Wrongdoing. In Pontell H.N., Geis G. (Eds). International Handbook of White-Collar and Corporate Crime (pp. 50-77). Boston: Springer.

Lever J., and Milbourne P. (2017) 'The structural invisibility of outsiders: The role of migrant labour in the meat-processing industry'. Sociology, 51(2), 306-322.

Lith, P. (2012) Kiinteistöala Suomen kansantaloudessa. Muistio kiinteistöalan yritystoiminnasta, markkinoista ja kehityslinjoista 2010-11 (translation: The real estate industry in the Finnish economy. A memorandum on business, markets and developments in the real estate industry 2010-11). Suunnittelu- ja tutkimuspalvelut Pekka Lith, Helsinki, 7 January 2012.

Lloyd A. (2018) Working for free illegal employment practices, "off the books" work and the continuum of legality within the service economy. Trends in Organised Crime. Epub ahead of print, 15 September 2018. DOI: 10.1007/s12117-018-9351-x.

Lord N, Elizondo CF, and Spencer J (2017) The dynamics of food fraud: the interactions between criminal opportunity and market (dys)functionality in legitimate business. Criminology and Criminal Justice 17(5), 605-623.

Lord, N. (2014). Regulating Corporate Bribery in International Business: Anti-Corruption in the $U K$ and Germany. Surrey: Ashgate. 
Nietsch, M. (2017). Corporate illegal conduct and directors' liability: An approach to personal accountability for violations of corporate legal compliance. Journal of Corporate Law Studies. Published online 30 Aug 2017.

O'Connell Davidson, J. (2010). New Slavery, Old Binaries: Human Trafficking and the Borders of 'Freedom'. Global Networks: A Journal of Transnational Affairs, 10(2), 244-261.

Ollus, N. (2016a). From Forced Flexibility to Forced Labour: The Exploitation of Migrant Workers in Finland. Academic dissertation. HEUNI Report series No. 84.

Ollus, N. (2016b). Forced Flexibility and Exploitation: Experiences of Migrant Workers in the Cleaning Industry. Nordic journal of working life studies, 6(1), 25-45.

Ollus, N. and Alvesalo-Kuusi, A. (2012). From cherry-picking to control: migrant labour and its exploitation in Finnish governmental policies. Nordisk tidsskrift for Kriminalvidenskab, 3/99, 376-399.

Ollus, N. and Jokinen, A. (2013). We've got people lined up behind the door: placing the trafficking and exploitation of migrant workers in context in the restaurant and cleaning sectors in Finland. In Ollus, N, Jokinen, A., and Joutsen, M. (Eds.). Exploitation of migrant workers in Finland, Sweden, Estonia and Lithuania: Uncovering the links between recruitment, irregular employment practices and labour trafficking, (pp. 31-170). HEUNI Report series no. 75 .

Pearce, F. \& Tombs, S. (1998). Toxic Capitalism: Corporate Crime and the Chemical Industry. Aldershot: Ashgate.

Pemberton S. (2015) Harmful Societies: Understanding Social Harm. Bristol: Policy Press.

Refslund, B. (2014) Intra-European labor migration and deteriorating employment relations in Danish cleaning and agriculture: industrial relations under pressure from EU8/2 labor inflows? Economic and Industrial Democracy 31 October 2014 (published online), 1-25.

Ruggiero, V. \& South, N. (2010). Critical Criminology and Crimes Against the Environment. Critical Criminology, 18, 245-250.

Scott, S. (2017) Labour Exploitation and Work-Based Harm. Bristol: Policy Press.

Skrivankova, K. (2010). Between decent work and forced labour: examining the continuum of exploitation. York: Joseph Rowntree Foundation. 
Snider, L. (1991). The Regulatory Dance: Understanding Reform Processes in Corporate Crime, International Journal of the Sociology of Law, 19, 209-236.

Snider, L. (2009). Accommodating Power: The 'Common Sense' of Regulators. Social \& Legal Studies, 18(2), 179-197.

Standing, A. (2015) Corruption and state-corporate crime in fisheries. Bergen: Anti-Corruption Resource Centre.

Stevens, G.C. (1989). Integrating the Supply Chain. International Journal of Physical Distribution \& Materials Management, 19(8), 3-8.

Stone, K. V.W. (2005) Flexibilization, Globalization, and Privatization: Three Challenges to Labor Rights in Our Time. Osgoode Hall Law Journal, Fall 2005; UCLA School of Law Research Paper No. 05-19.

Tombs, S. \& Whyte, D. (2015). The Corporate Criminal. Why Corporations Must Be Abolished. London and New York, NY: Routledge.

Wilkinson, M. and Craig, G. (2011). Wilful negligence: migration policy, migrants' work and the absence of social protection in the UK. In Carmel, E., Cerami,A. and Papadopoulos, T. (Eds.). Migration and welfare in the new Europe: Social protection and the challenges of integration (pp. 177-194). Bristol: Policy Press.

Wilson, S. and Ebert, N. (2013). Precarious work: Economic, sociological and political perspective. The Economic and Labour Relations Review, 24(3), 263-278. 